Tomas Kucera

\title{
APPLICATION OF THE ACTIVTTY-BASED COSTING TO THE LOGISTICS COST CALCULATION FOR WAREHOUSING IN THE AUTOMOTIVE INDUSTRY
}

\begin{abstract}
Activity-based costing is one of the procedures that proved to be very suitable for the financial management of warehouse activities in the automotive industry. Accurate and up-to-date data enables managers to properly plan and manage all the warehousing related activities in the automotive industry. In the activity-based costing approach, overheads costs are allocated in relation to specific logistics activities of the company. The aim of the article is the application of activity-based costing to the logistics cost calculation for warehousing in the automotive industry. The article focuses on the practical application of activity-based costing to the logistics cost calculation for warehousing in the automotive industry to a particular logistics service provider. It highlights the positive and negative use of this method in the practical case study, which is one of the major qualitative scientific methods. The resulting effect of using the activity-based costing method should be to refine the information that is used for the decision-making problems of the top management of the logistics service provider.
\end{abstract}

Keywords: activity-based costing, logistics cost calculation for warehousing, automotive industry, logistics costs

\section{Introduction}

Logistics is today an area that has an irreplaceable role in the business. The chain of logistics activities ensures the smooth running of the production process and logistics costs are associated with each logistic activity. Those costs are not negligible items that affect to a large extent the overall profit or loss of a company. The need to monitor costs in terms of logistics activities is a prerequisite for identifying rationalization measures in logistics activities and optimizing the logistics costs of a company.

Logistic costs constitute an important percentage of the total costs in automotive industry [1]. Logistics activities take place in every supply channel, including customer service, warehousing, transportation, inventory management, information flow, and order processing [2]. Supply chain operations and logistics are vital tools for businesses to remain competitive in today's major economic activities [3-4]. Rutner and Langlev [5], Lambert and Burduroglo [6] and Lynch, Keller and Ozment [7] draw attention to the fact that logistics have been under pressure for a long time to reduce the costs of the company. As a result, the areas of logistics are explored, where the cost optimization options are focused on individual logistics activities and processes. Kucera [8] argues that logistics managers are usually interested in providing the high quality services to their customers at minimum costs. Logistics services have gradually become the only way for the third-party logistics companies to improve logistics capabilities and integrate logistics resources [9-10]. Bokor [11-12] notes that requirements for the quality of logistics services are getting higher and higher. At the same time, however, the financial resources available to companies are rather limited. In such a business environment, according to Bokor [13], logistics service providers have to pay special attention to the optimal allocation of resources in various decision-making tasks. It is a basic step in monitoring and evaluating logistics costs to support the decision-making tasks [14-15]. Logistics costs are a substantial part of an operation in a supply chain [16]. Logistics costs arise in different types of logistics activities in the automotive industry and affect material flow and accompanying financial and information flows; thanks to this fact, information support and evaluation are important tasks for the company [17]. Automotive companies have started to optimize logistics costs by implementing logistics cost management systems [18]. Warehousing costs and management has become a very important element in the supply chain in recent years because it is not just a centralized warehouse for goods and value-added services [19-20].

Currently, all the companies are striving for different techniques to create better supply chain management for their competitive advantage. Activity-based costing is one method that is typically used to improve the business performance, identify the high-cost activities, and measure logistics management performance [21-22].

Tomas Kucera*

Department of Transport Technology and Control, Faculty of Transport Engineering, University of Pardubice, Czech Republic

*E-mail of corresponding author: tomas.kucera@upce.cz 


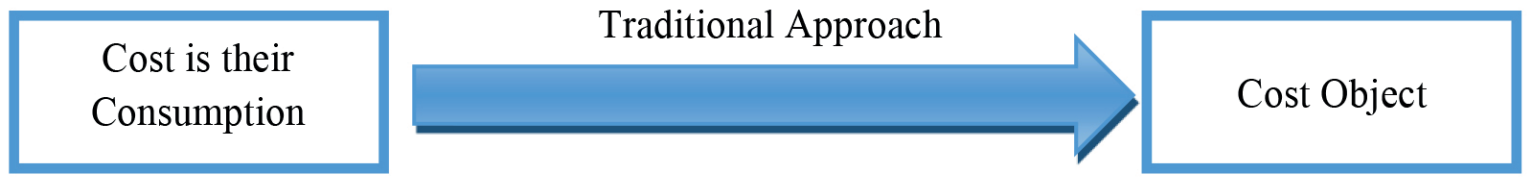

Activity-based Costing Method
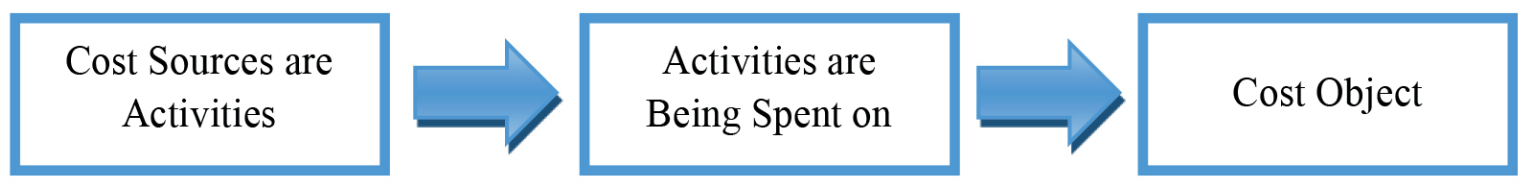

Figure 1 Comparison of traditional calculation methods and activity-based costing; based on [48] and [49]

The aim of this article is a practical application of activity-based costing to the logistics cost calculation for warehousing in the automotive industry to a particular logistics service provider. Article highlights the positive and negative use of this method in the practical case study, which is one of the major qualitative scientific methods. The real case study is the method of the qualitative research based on the study of one or a small number of situations for application of the findings for the similar cases according to Nielsen, Mitchell and Nørreklit [23].

\section{Theoretical background and methodology}

Logistics costs can be defined with respect to the basic concepts of logistics [24]. Logistics costs are created in different business areas and are classified by most studies as a percentage of goods sales. There are at least six individual cost components, namely transport, warehousing, inventory management, administration of logistics, packaging and indirect logistics costs [25-29]. The percentage of logistics costs is approximately 10 $\%$ of the gross domestic product [30-32], so managing and optimizing logistics costs is crucial to society [33]. Jonsson [34] defines the costs that can be attributed to logistics. There are large differences in logistics costs between companies in various industries; several scientific studies [35-38] report that their share of the company's revenue is at least 6 percent. This percentage varies considerably between $6 \%$ and $25 \%$, but they all agree that the share of logistics costs is the lowest in automotive companies.

Feng at al. [39] and Tu and Wang [40] find that finding efficient methods in the process of calculating logistics costs is very difficult nowadays, but it is a topical issue in the area of logistics cost management.

Yin [41] and Yuqin [42] present that through the cost management process, costs can be effectively reduced and resources efficiently allocated. The goal of logistics cost management is to reduce costs and increase the competitiveness of logistics service providers. Yin [41] and Lijun [43] argue that logistics costs are divided into many industries and this makes it difficult to obtain relevant information from managerial accounting.

A significant part of the logistics tasks are implemented by logistics service providers, these companies play a key role in the more efficient and efficient operation of selected industries. Therefore, their operation must be effective enough, which means that logistics service providers must be aware of the main operational factors of logistics processes. These processes should be monitored and evaluated through management information systems.

Bokor [12] emphasizes that the costing of logistics costs has become a challenge in logistics and supplychain management. Bokor and Markovits-Somogyi [44] state that it is necessary to obtain reliable and accurate information about the structure of the calculations to achieve efficient allocation of resources within the logistics service provider. Traditional approaches to calculations may not be sufficient to achieve this goal in the case of complex and heterogeneous logistics services.

Bokor and Markovits-Somogyi [44] and Bokor [45] claim that traditional costing methods are not always able to provide the information necessary to support decision-making in the required quality. They may even disrupt the cost calculations of logistics services, so it is necessary to implement appropriate costing methods that improve the accuracy and reliability of the data obtained. According to [44], one of the applicable methods is activity-based costing.

Griful-Miquela [46] considers improving the allocation of overheads costs as the most important difference between conventional costing methods and activity-based costing. The use of overriding methods was appropriate in the past when work was a major component of costs. In the activity-based costing approach, overheads costs are allocated in relation to specific logistics activities of the company.

Stevenson and Cabell [47] Gros and Grosova [48] and Gros, Barancik and Cujan [49] draw attention to the fact that while traditional costing directly allocates resources to cost objects, the activity-based costing method advances in two stages. First, the resources are assigned to the individual activities and in the next 


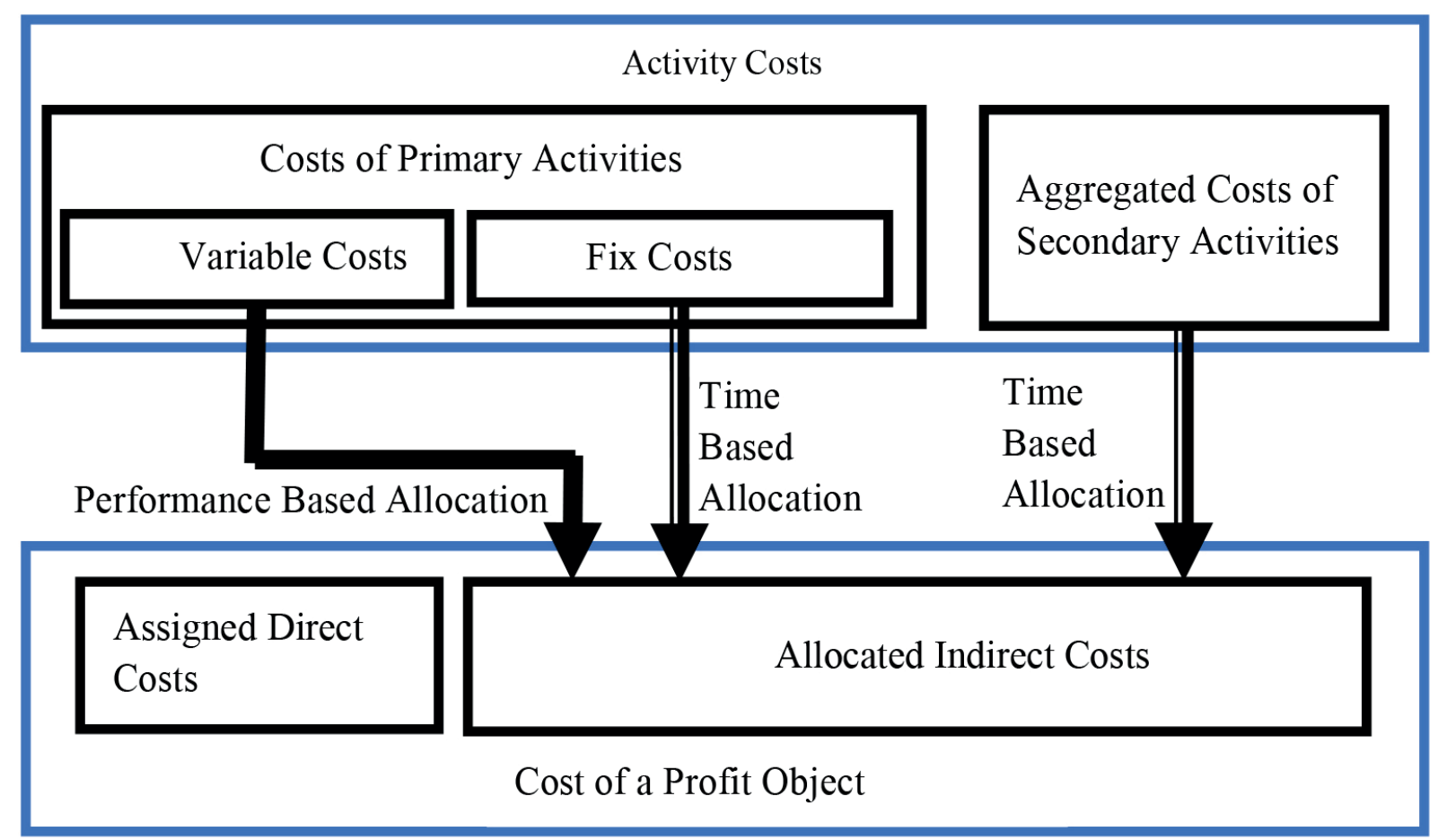

Figure 2 Activity-based costing model; [44]

step to the individual entities. The difference between traditional costing and activity-based costing is shown in Figure 1.

Bokor and Markovits-Somogyi [44] present that, given the general characteristics and the current adaptation of the activity-based costing method, the costs of certain logistics services consist of four parts (see Figure 2):

- Direct costs derived from the accounting system.

- Variable indirect costs from primary activities, the allocation is based on performance.

- Fixed indirect costs arising from primary activities, the allocation is based on time consuming.

- Indirect costs from the secondary activities, the allocation is time-based.

Time consuming is the total duration of logistics services (transport, warehousing and sometimes-other activities).

Primary activities are indexed as $\mathrm{i}=1 \ldots \mathrm{n}$, while profit objects, i.e. logistics services, are indexed as $\mathrm{j}=1 \ldots \mathrm{m}$. The Equation (1), which consists of four components, is used to calculate costs.

$$
\begin{aligned}
C_{j}= & C_{j}^{d}+\sum_{i=1}^{n} C_{v i} \frac{P_{j i}}{P_{i}}+\frac{T_{j}}{\sum_{j=1}^{m} T_{j}} \sum_{i=1}^{n} C_{f_{i}}+ \\
& +\frac{T_{j}}{\sum_{j=1}^{m} T_{j}} C^{\mathrm{s} a}[\mathrm{CZK}]
\end{aligned}
$$

where:

$C_{j} \quad$ Cost of profit object j [CZK],

$C_{j}^{d} \quad$ Direct cost of profit object j [CZK],

$C_{v i}$ Variable cost of primary activity i [CZK],

$P_{i} \quad$ Performance of primary activity i [differently expressed power units],
$P_{j i}$ Performance consumption of profit object $\mathrm{j}$ at primary activity i [differently expressed power units],

$T_{j} \quad$ Time consumption of profit object $\mathrm{j}$ [hours],

$C_{f_{i}}$ Fix cost of primary activity i [CZK],

$C^{s a}$ Aggregated costs of secondary activities [CZK].

The four components can be merged into three components:

- Assigned direct cost.

- Allocated variable indirect cost, allocation is based on relative performance consumptions.

- Allocated fix indirect cost, allocation is based on the relative time consumption:

$$
\begin{aligned}
C_{j}= & C_{j}^{d}+\sum_{i=1}^{n} C_{v i} \frac{P_{j i}}{P_{i}}+\frac{T_{j}}{\sum_{j=1}^{m} T_{j}} . \\
& \cdot\left(\sum_{i=1}^{n} C_{f_{i}}+C^{s a}\right)[\mathrm{CZK}]
\end{aligned}
$$

The cost efficiency, i.e. the average costs of a primary activity (as service generator) can be calculated as follows:

$$
\begin{aligned}
c_{i}= & \frac{C_{i}}{P_{i}}=\frac{C_{v_{i}}+C_{f_{i}}}{P_{i}} . \\
& \cdot\left[\frac{\mathrm{CZK}}{\text { differently }} \text { expressed power units }\right]
\end{aligned}
$$

where: $C_{i}$ Cost of primary activity in [CZK].

The implementation of the activity-based costing method consists of 6 consecutive steps; these steps are specifically illustrated in Figure 3. 


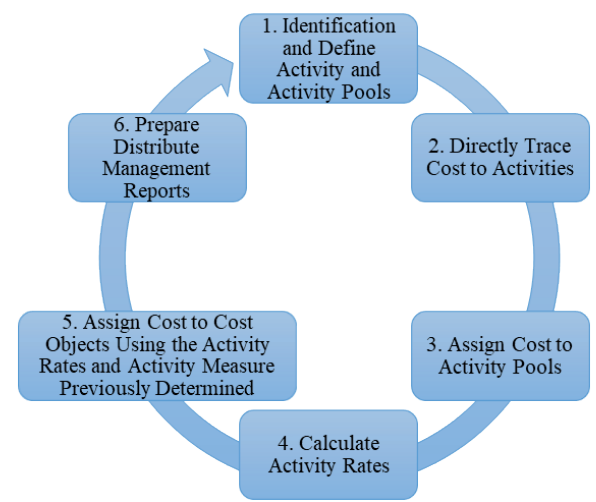

Figure 3 Six steps of implementing the activity-based costing method; based on [50] and [51]

\section{Results and discussion}

The aim of this article is a practical application of the activity-based costing to the logistics cost calculation for warehousing in the automotive industry to a particular logistics service provider. The article highlights the positive and negative use of this method in the practical case study.

The chosen logistics service provider in the automotive industry provides transport services to a large number of customers.

In addition to transport, it provides other logistics services. Services offered in logistics are:

- Internal logistics (warehousing and supply of assemblies).

- Receipt of goods and expedition.

- Warehousing and supply to manufacturing plants.

- Repackaging, pick and pack, material sorting.

- Batch, serial and data reports.

- $\quad$ Picking including kit (i.e. assembling components into sets or kits).

- Sorting and checking all the components.

- $\quad$ FIFO (First In - First Out), Kanban.

- Delivery in JIT (Just in Time) and JIS (Just in Sequence) mode.

- Cross-docking including the added services mentioned above.

- $\quad$ Light pre-production.

- Packaging cleaning, handling and removal of empty packaging.

It is the trend of using new approaches in logistics cost calculations for logistics service providers with regard to the automotive industry in the last few decades. This industry is one of the leading players in advanced economies. A significant competitive advantage can arise with the correct calculation of logistic warehousing costs. Logistics service providers look at the appropriate use of new approaches and use the activity-based costing method. It uses preliminary calculations from the entire computing system to support price decisions as a part of the calculations. Logistics cost calculations always reflect the specific requirements of the automotive customers. It is always a specific type and scope of provided service.

As a part of the calculation of logistics costs, a cost structure is created, more in Table 1 . The resulting calculation is always one unit of measure (product, euro pallet). The logistics costs are precisely structured to meet the specific needs of the automotive customers. All the requirements and wishes that the customer has for the required service must always be met.

Logistics cost calculation includes:

- Area.

- Energy.

- Racking system.

- Handling equipment.

- Transport.

- Warehouse staff.

- Other costs.

- Hardware and software.

Area, energy and racking systems are negligible in this particular logistics cost calculation in the automotive industry. It is already rented area and equipped with racking system including the whole energy consumption.

The allocation of handling equipment costs is based on customer product warehousing requirements and the necessary handling equipment to handle the product. These are different types of forklifts, pallet truckers and others pickers and hand pallet trucks.

The transport costs are calculated per $\mathrm{km}$ per specific vehicle, which is used for transport within the shuttle. Furthermore, transport costs include a passenger car, the costs of other possible transports.

The logistics service provider calculates the warehouse staff costs per worker in a particular job (white collar, blue collar). Total personnel costs per worker are calculated. In addition to payroll costs, social costs, statutory insurance and liability insurance, costs include protective equipment, training, contributions to cultural and sporting events, and other logistics service provider bonuses.

Other costs include insurance costs, security, facility management, consumables, re-certification and waste costs. Other costs also include unexpected costs 
Table 1 Logistics cost calculation for warehousing in the automotive industry

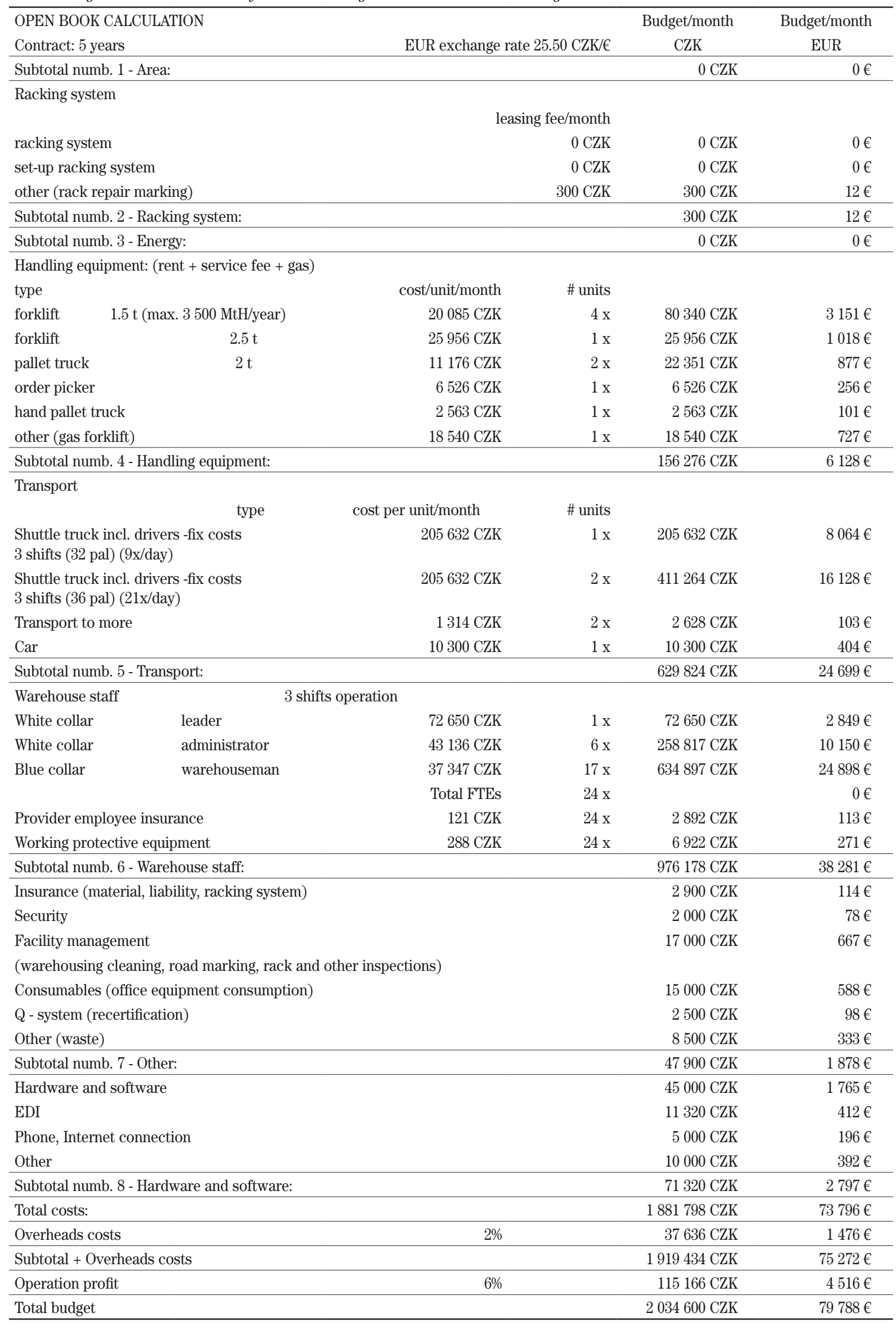


that may be costs associated with delays in starting production or unexpected situations that may occur.

The costs associated with information technology (hardware and software) are focused on equipping the warehouse with all the information technologies, electronic data interchange, phone, Internet connection and other costs which have connection with information technology.

The last part of the logistics cost calculation is overheads costs (2.00\%), which includes management, accounting, controlling, auditing and personal vehicle management costs. The calculation also includes a 6.00 $\%$ operation profit.

\section{Conclusion}

Logistics coordination and synchronization of material, information and financial flow hits the company at a conflict of partial goals that are monitored by individual organizational units and are very diverse and often contradictory. Logistics is not an end in itself, but it is a part of an entrepreneurial strategy, both a customer-driven business management concept and a rationalizing tool. Warehousing and warehousing costs play an important role in all the aspects of supply chain management. The provision of warehouse services is focused on the level (availability) needed to meet demand. Costs for logistics processes can be characterized as costs associated with logistics activities, respectively business processes. Logistics costs become unproductive, for example, when stockpiles are overstocked, inappropriate transport mode selection, uncontrolled handling of goods, etc. Optimization of costs in logistic activities, namely processes can be carried out based on the standard tools by reducing costs at a general level, i.e. through the cost reductions, which are measures related to the use of reserves in logistics processes. The main aim of the article was application of the activity-based costing to the logistics cost calculation for warehousing in the automotive industry. The application was shown on the real case study from the field of the automotive industry.

\section{Acknowledgement}

The work was created in connection with the scientific research project of the University of Pardubice no. SGS_2019_010. The author is grateful for their support.

\section{References}

[1] MARQUEZ, F. P. G., PARDO, I. P. G., NIETO, M. R. M. Competitiveness based on logistic management: a real case study. Annals of Operations Research [online]. 2015, 233(1), p. 157-169. ISSN 0254-5330, eISSN 1572-9338. Available from: https://doi.org/10.1007/s10479-013-1508-Z

[2] WIRATCHAI, A., LILAVANICHAKUL, A., PARTHANADEE, P. Analysis of logistics costs for rice mills in improving the aroma of jasmine rice. 3rd International Conference on Agro-Industry - Competitive \& Sustainable Agro-Industry: proceedings [online]. 2018. ISSN 2413-0877, p. 146-153. Available from: https://doi.org/10.18502/kls.v4i2.1666

[3] YANG, C. S., LU, C. S., XU, J., MARLOW, P. B. Evaluating green supply chain management capability, environmental performance, and competitiveness in container shipping context. Journal of the Eastern Asia Society for Transportation Studies [online]. 2013, 10, p. 2274-2293. ISSN 1881-1124. Available from: https://doi.org/10.11175/easts.10.2274

[4] WU, D., HUO, J., ZHANG, G., ZHANG, W. Minimization of logistics cost and carbon emissions based on quantum particle swarm optimization. Sustainability [online]. 2018, 10(10), p. 1-15. ISSN 2071-1050. Available from: https://doi.org/10.3390/su10103791

[5] RUTNER, S. M., LANGLEY, C. J. Logistics value: definition, process and measurement. The International Journal of Logistics Management [online]. 2000, 11(2), p. 73-82. ISSN 0957-4093. Available from: https://doi.org/10.1108/09574090010806173

[6] LAMBERT, D. M., BURDUROGLO, R. Measuring and selling the value of logistics. The International Journal of Logistics Management [online]. 2000, 11(1), p. 1-16. ISSN 0957-4093. Available from: https://doi.org/10.1108/09574090010806038

[7] LYNCH, D. F., KELLER, S. B., OZMENT, J. The effects of logistics capabilities and strategy on firm performance. Jourmal of Business Logistics. 2000, 21(2), p. 47-68. ISSN 2158-1592.

[8] KUCERA, T. Logistics cost calculation of implementation warehouse management system: a case study. MATEC Web of Conferences [online]. 2017, 134, p. 1-7. ISSN 2261-236X. Available from: https://doi.org/10.1051/matecconf/201713400028

[9] QIU, M., MING, Z., LI, J., GAI, K., ZONG, Z. Phase-change memory optimization for green cloud with genetic algorithm. IEEE Transactions on Computers [online]. 2015, 64(12), p. 3528-3540. ISSN 0018-9340. Available from: https://doi.org/10.1109/TC.2015.2409857

[10] XUE, Y., GE, L. Cost optimization control of logistics service supply chain based on cloud genetic algorithm. Wireless Personal Communications. 2018, 102(4), p. 3171-3186. ISSN 0929-6212, eISSN 1572-834X. 
[11] BOKOR, Z. A koltseggazdalkodas korszerusitese a kozlekedesben, kulonos tekintettel a kozossegi kozlekedesre / Improving cost calculation in transport with special regard to public transport (in Hungarian). Kozlekedestudomanyi Szemle / Review of Transportation Sciences. 2008, 58(4), p. 31-36. ISSN 0023-4362.

[12] BOKOR, Z. Elaborating cost and performance management methods in transport. Promet - Traffic\&Transportation, Scientific Journal on Traffic and Transportation Research [online]. 2009, 21(3), p. 217-224. ISSN 0353-5320, eISSN 1848-4069. Available from: https://doi.org/10.7307/ptt.v21i3.228

[13] BOKOR, Z. Cost calculation in complex transport. LOGI Scientific Journal on Transport and Logistics. 2013, 4(1), p. 5-22. ISSN 1804-3216, eISSN 2336-3037.

[14] KUCERA, T., HYRSLOVA, J., SOMMERAUEROVA, D. Activity-based costing as an innovative management method to logistics cost calculation for warehousing. 4th International Multidisciplinary Scientific Conference on Social Sciences \& Arts SGEM 2017 : proceedings. Book 1, Vol. 5. 2017. ISBN 978-619-7408-17-1, ISSN 2367-5659, p. 25-32.

[15] KUCERA, T., Cost management in logistics of warehousing: the use of activity-based costing in the logistics service provider. International Conference on Traffic and Transport Engineering: proceedings. 2018. ISBN 978-86-916153-4-5, p. 449-453.

[16] MUSCATELLO, J. R., PARENTE, D. H., SWINARSKI, M. Aligning supply chain logistics costs via ERP coordination. International Journal of Information System Modelling and Design [online]. 2018, 9(2), p. 24-43. ISSN 1947-8186. Available from: https://doi.org/10.4018/IJISMD.2018040102

[17] KOVRIZHNYKH, O. E., NECHAEVA, P. A. Analysis of transaction costs in logistics and the methodologies for their information reflection for automotive companies. Economic and Social Changes-Facts Trends Forecast [online]. 2016, 44(2), p. 186-201. ISSN 2307-0331. Available from: https://doi.org/10.15838/esc.2016.2.44.11

[18] SKERLIC, S., MUHA, R. The Importance of systems for controlling logistics costs in the supply chain: a case study from the Slovenian automotive industry. Promet - Traffic\&Transportation, Scientific Journal on Traffic and Transportation Research. 2016, 28(3), p. 299-310. ISSN 0353-5320, eISSN 1848-4069.

[19] DE KOSTER, M. B. M. Recent developments in warehousing. Rotterdam Erasmus University: Rotterdam School of Management, 1998.

[20] CHOY, K. L., CHOY, E. L. H., POON, T. C. A Real-time database management system for logistics systems: a case study. Portland International Conference on Management Engineering and Technology [online] 2008, p. 864-871. ISSN 21595100. Available from: https://doi.org/10.1109/PICMET.2008.4599694

[21] ASKARANY, D., YAZDIFAR, H., ASKARY, S. Supply chain management, activity-based costing and organisational factors. International Journal Production Economics [online]. 2010, 127(2), p. 238-248. ISSN 0925-5273, eISSN 18737579. Available from: https://doi.org/10.1016/j.ijpe.2009.08.004

[22] KOLOSOWSKI, M., CHWASTYK. P. Process approach in enterprise aided with activity based costing. 20th DAAAM International Symposium on Intelligent Manufacturing and Automation: proceedings. 2009, ISBN 978-1-5108-4001-0, p. 1117-1119.

[23] NIELSEN, L. B., MITCHELL, F., NORREKLIT, H. Management accounting and decision making: two case studies of outsourcing. Accounting Forum [online]. 2015, 39(1), p. 64-82. ISSN 0155-9982. Available from: https://doi.org/10.1016/j.accfor.2014.10.005

[24] STERNAD, M. Metrics of logistics costs in Slovenian companies. $18^{\text {th }}$ International Scientific Conference Business Logistics in Modern Management: proceedings. 2018. ISSN 1849-5931, p. 125-134.

[25] ZENG, A., ROSSETTI, C. Developing a framework for evaluating the logistics costs in global sourcing processes. International Journal of Physical Distribution \& Logistics Management [online]. 2003, 33(9), p. $785-803$. ISSN 0960-0035. Available from: https://doi.org/10.1108/09600030310503334

[26] FUGATE, B. S., MENTZER, J. T., STANK, T. P. Logistics performance: efficiency, effectiveness, and differentiation. Journal of Business Logistics [online]. 2010, 31(1), p. 43-62. ISSN 2158-1592. Available from: https://doi.org/10.1002/j.2158-1592.2010.tb00127.x

[27] ENGBLOM, J., SOLAKIVI, T., TOYLI, J., OJALA, L. Multiple-method analysis of logistics costs. International Journal of Production Economics [online]. 2012, 137(1), p. 29-35. ISSN 0925-5273, eISSN 1873-7579. Available from: https://doi.org/10.1016/j.ijpe.2012.01.007

[28] SKERLIC, S. The Impact of customers' demands for lower logistics costs in the automotive industry supply chain on companies' business processes. Zeszyty Naukowe Akademii Morskiej w Szczecinie / Scientific Journals Of the Maritime University of Szczecin [online]. 2018, 55(127), p. 86-92. ISSN 1733-8670, eISSN 2392-0378. Available from: https://doi.org/10.17402/305

[29] VON CEIMINSKI, G., KARRER, M., ZUR, M. Designing and implementing a framework for process-oriented logistics-costs measurement in an automotive-supplier group. Advances in Production Management Systems: New Challenges, New Approaches APMS 2009: proceedings. [online]. Vol. 338. IFIP Advances in Information and Communication Technology. Berlin, Heidelberg: Springer, 2010. ISSN 1868-4238, p. 499-505. Available from: https://doi.org/10.1007/978-3-642-16358-6_62 
[30] RANTASILA, K., OJALA, L. Measurement of national level logistics costs and performance. 2012 Summit of the International Transport Forum, on Seamless Transport: Making Connections: Discussion Paper, No. 2012-4 [online]. 2012. eISSN 2223439X. Available from: https://doi.org/10.1787/2223439X

[31] HAVENGA, J. Macro-logistics and externality cost trends in South Africa - underscoring the sustainability imperative. International Journal of Logistics Research and Applications [online]. 2015, 18(2), p. 118-139. ISSN 1367-5567. Available from: https://doi.org/10.1080/13675567.2015.1015509

[32] WILSON, R. Ready for a new route. CSCMP's 25th Annual State of Logistics Report. 2015.

[33] STERNAD, M., KNEZ, M. Pomen obvladovanja logisticnih stroskov, logisticni sistemi prihodnosti (in Slovenian). The importance of logistics costs management, logistic systems of the future. Maribor: Visja Prometna Sola, 2008, p. $40-44$.

[34] JONSSON, P. Logistics and supply chain management. Berkshire: McGraw-Hill Higher Education, 2008. ISBN 978-00-7711-738-2.

[35] OJALA, L., SOLAKIVI, T., HALINEN, H., LORENTU, H., HOFFMANN, T. Logonbaltic - state of logistics in the Baltic sea region, survey results from eight countries. LogOn Baltic master reports, 3. Turku: Turku School of Economics, University of Turku, 2007.

[36] BAYKASOGLU, A., KAPLANOGLU, V. Application of activity-based costing to a land transportation company: a case study. International Journal of Production Economics [online]. 2008, 116(2), p. 308-324. ISSN 0925-5273, eISSN 1873-7579. Available from: https://doi.org/10.1016/j.ijpe.2008.08.049

[37] HANSEN, W., HOVI, I. B., VEISTEN, K. Logistics costs in Norway: comparing industry survey results against calculations based on a freight transport model. International Journal of Logistics Research and Applications [online]. 2014, 17(6), p. 485-502. ISSN 1367-5567. Available from: https://doi.org/10.1080/13675567.2014.899568

[38] RANTASILA, K., OJALA, L. National-level logistics costs: an overview of extant research. International Journal of Logistics Research and Applications [online]. 2015, 18(4), p. 313-324. ISSN 1367-5567. Available from: https://doi.org/10.1080/13675567.2015.1016413

[39] FENG, G. Z. The calculation and evaluation of enterprise logistics cost. Beijing: Machine Press, 2007. ISSN 1816-6075.

[40] TU, CH., WANG, A. On calculation of enterprise logistics cost with project accounting function of financial software. Journal of System and Management Sciences. 2011, 1(4), p. 71-82. ISSN 1816-6075, eISSN 1818-0523.

[41] YIN, M. Analysis and solutions of enterprises logistic cost management. Management World. 2007, 32, p. 36-41. ISSN 1002-5502.

[42] YUQIN, Z. Measures on reducing enterprise logistic cost. Logistic Economy. 2007, 33, p. 5-12.

[43] LIJUN, Z. Management of logistic cost based on activity analysis. Commercial Economic. 2007, 22, p. 21-28.

[44] BOKOR, Z., MARKOVITS-SOMOGYI, R. Applying activity-based costing at logistics service providers. Periodica Polytechnica Transportation Engineering [online]. 2015, 43(2), p. 98-105. ISSN 0303-7800, eISSN 1587-3811. Available from: https://doi.org/10.3311/PPtr.7700

[45] BOKOR, Z. Improving transport costing by using operation modelling. Transport [online]. 2012, 26(2), p. 128-132. ISSN 1648-4142. Available from: https://doi.org/10.3846/16484142.2011.586111

[46] GRIFUL-MIQUELA, C. Activity-based costing methodology for third-party logistics companies. International Advances in Economic Research [online]. 2001, 7(1), p. 133-146. ISSN 1083-0898, eISSN 1573-966X. Available from: https://doi.org/10.1007/BF02296598

[47] STEVEnSON, T. H., CABELL, D. W. E. Integrating transfer pricing policy and activity-based costing. Journal of International Marketing [online]. 2002, 10(4), p. 77-88. ISSN 1547-7215. Available from: https://doi.org/10.1509/jimk.10.4.77.19552

[48] GROS, I., GROSOVA, S. Dodavatelske systemy / Supply chain management (in Czech). Prerov: Vysoka skola logistiky, 2012. ISBN 978-80-87179-20-8.

[49] GROS, I., BARANCIK, I., CUJAN, Z. Velka kniha logistiky / Great book of logistics (in Czech). Praha: Vysoka skola chemicko-technologicka v Praze, 2016. ISBN 978-80-7080-952-5.

[50] GARRISON, H. R., NOREEN, E. W., BREWER, P. C. Managerial accounting. Boston: McGraw-Hill Education, 2017. ISBN 978-12-5930-741-6.

[51] WATANAPA, A, PHOLWATCHANA, S., WIYARATN, W. Activity-based costing analysis for train station's service. Engineering Journal [online]. 2016, 20(5), p. 135-144. ISSN 0125-8281. Available from: https://doi.org/10.4186/ej.2016.20.5.135 